\title{
Analysis of an Asynchronous Online Discussion as a Supportive Model for Peer Collaboration and Reflection in Teacher Education
}

\author{
Romina Plešec Gasparič and Mojca Pečar \\ Faculty of Education, University of Ljubljana, Slovenia
}

\author{
romina.plesec@pef.uni-li.si mojca.pecar@pef.uni-li.si
}

\begin{abstract}
Professional development of future teachers is based on connecting theory and practice with the aim of supporting and developing critical, independent, responsible decision-making and active teaching. With this aim we designed a blended learning environment with an asynchronous online discussion, enabling collaboration and reflection even when face-to-face communication was not possible. This paper discusses the constructs of social and cognitive components, reflection and collaborative learning in blended learning environments. It presents the results of a study that was conducted on a sample of pre-service primary school teachers studying at the largest faculty of education in Slovenia. The purpose of the study was to determine the intensity, level and content of students' posts in the online discussion, how students assess its usefulness, and whether there are differences in the assessment of goals achieved in teaching practice between the students who were included in the online discussion and those who were not. We found that in the sub-groups where communication between students participating in the online discussion did not develop at the level of interpersonal relations, it also failed to develop at the level of learning. We also found that the online discussion helped the participating students to plan their lessons. In assessing the achieved practical teaching goals, it became obvious that the online discussion had a positive impact on students' perception about adapting their lessons, as well as on their critical assessment in analysing their teaching.
\end{abstract}

Keywords: teacher education, reflection, collaboration, blended learning environment, asynchronous online discussion, social and cognitive components of interaction.

\section{Introduction}

In higher education, we tend to form a research-oriented, reflective and critical study environment that enables in-depth study. Quality programmes for future teachers are based on a balanced

Material published as part of this publication, either on-line or in print, is copyrighted by the Informing Science Institute. Permission to make digital or paper copy of part or all of these works for personal or classroom use is granted without fee provided that the copies are not made or distributed for profit or commercial advantage AND that copies 1) bear this notice in full and 2) give the full citation on the first page. It is permissible to abstract these works so long as credit is given. To copy in all other cases or to republish or to post on a server or to redistribute to lists requires specific permission and payment of a fee. Contact Publisher@InformingScience.org to request redistribution permission. combination of theory and practical experience, and thus teachers embarking on an independent career face less problems (Valenčič Zuljan \& Vogrinc, 2007). In the process of acquiring initial practical teaching experience, the focus is on critical reflection of one's own actions and professional development, which Valenčič Zuljan (2001, as cited in Vogrinc \& Valenčič Zuljan, 2009) defines as: 
a process of significant and lifelong empirical learning in which teachers develop their own comprehensions, and are changing their teaching practice; it is the process which includes teachers' individual, professional and social dimensions, and it is also teachers' progressing towards the direction of critical, independent, responsible decisionmaking and acting. (p. 54)

Teaching practice does not only involve accumulating knowledge; it is primarily a process of reaching professional maturity in which students develop the skill of reflecting upon their own professional work (Valenčič Zuljan \& Vogrinc, 2012). Antoniou, Kyriakides, and Creemers (2011) point out that reflection is most efficient when focused on the problem and the area that the student wishes to improve. Students have to know exactly what and how to reflect; otherwise, their reflection can become merely a routine activity. Reflecting on various issues and topics has to be encouraged on various levels and at different times (prior to, during and after teaching), as well as individually, in groups and with a mentor (Jay \& Johnson, 2002; Killion \& Todnem, 1991; Korthagen, 2004; Kreber, 2004; Mezirow, 1990; O’Hanlon, 1991; Schön, 1983; Ward \& McCotter, 2004).

Since students have not yet acquired a complex insight into the deeper meaning of their own actions, it is recommended that critical friends are introduced into their reflection to help these students thoroughly talk over their work (Schollaert, 2006). This is also supported by Korthagen and Vasalos (2005), who emphasize that the reflection and collaboration of students have to be encouraged and guided during their studies. In-person collaboration is often not possible due to various limitations, which has led to the development of computer-supported collaborative learning (CSCL). CSCL endeavours to overcome certain barriers which occur in the process of live collaborative learning, such as: (a) effective participation of all group members in developing ideas; (b) guiding different methods of contributing and participating in the desired direction; (c) overcoming barriers due to the geographical distance of members; and (d) lack of time to carry out the programme (Fee, 2009, as cited in Bregar, Zagmajster, \& Radovan, 2010; Stahl, 2005). CSCL is distinguished by its flexibility and diversity of communication, easy access and openness of knowledge resources, as well as the option of independent study of materials and searching for solutions (Bregar et al., 2010). Sorden and Munene (2013) suggest that "blended learning featuring collaboration and social presence can help institutions create better programs and support services that may lead to more effective learning environments" (p. 252).

Any online learning environment should provide a high level of interaction between students, teachers and students (social component), and between students and teaching content (cognitive component). The third component is the teaching technology that enables the functioning of the social and cognitive components (Whaley, 2002, as cited in Rebolj, 2008). In this respect, Bregar et al. (2010) point out that technology cannot replace learning as a social process, but it can improve it. Since brief incidental interactions do not suffice to lead from learning to knowledge, it is better to focus on group interaction, with words and conversation leading to common meaning, which enables learning and leads to knowledge. Ma (2008) is of the opinion that CSCL also improves the learning progress of the individual and the group through constructive criticism among group members. Members reflect on their own work and the work of others, interchanging their feedback. To make it more effective, reflection has to be planned; participants need to be given sufficient time in order to develop their skills of reflection, and their communication should take place in a socially encouraging environment.

The significance of well-being in an online study environment was studied by Rovai (2002), who found that there is a statistically significant connection between the perception of well-being in an online study environment and the perception of one's own learning. He explains that students who have a stronger feeling of affiliation and connection within the online study environment and perceive their own learning to be of a higher quality feel less isolated and more satisfied with 
their studies. Sorden and Munene (2013) also confirm a strong relationship between students' perceived collaboration and student satisfaction with the perceived social presence as the basis for collaboration. Social and cognitive learning components are intertwined and mutually dependent in group work. The social component, or the interpersonal element of group activity, is connected with the mode of dialogue and monologue of group members, as well as with their readiness to cooperate and mutually influence one another. The cognitive component, or the substantive element of group activity, shows how individual group members think, how they develop their ideas during conversation, and how a common understanding is formed.

If the interpersonal element of group members is more focused on competition and individual problem-solving, this will prevent them from achieving joint and simultaneous action and thus a common understanding of the same contents (Barron, 2003).

\section{Online Discussion}

Modern technology facilitates various methods of cooperation, one of them being online discussion. Harris and Sandor (2007) have found that there is a growing use of online discussion in tertiary education, which gives rise to the need for developing and familiarising with new approaches in the use of online discussion. From the point of view of accessibility, it enables participation at various times from practically any location, increases social interaction among students, and establishes a virtual space for the exchange of knowledge and reflection (Bryce, 2014; Garrison \& Cleveland-Innes, 2005; Hrastinski, 2008). The discussion can either be synchronous or asynchronous. A synchronous discussion takes place in real time and requires simultaneous cooperation of students and the teacher (Romiszowski \& Mason, 1996). It is suitable for simpler exchange of information (such as work planning, expressing mutual support); its participants experience a similar excitement as in live contacts (Hrastinski, 2008; Robert \& Dennis, 2005). Its advantage is that it takes place in real time, while its disadvantages include difficulties in ensuring that all participants are simultaneously online, the complexity of moderating such a discussion, and the insufficient time available to participants for reflection (Brannon \& Essex, 2001).

Participation in an online learning environment should surpass mere socialising and a simple exchange of experiences. For this reason, an asynchronous online discussion is more suitable for more complex topics and for encouraging participation at the cognitive level. Garrison (2003) maintains that two basic features of asynchronous e-learning are absence of time constraint and connection. The absence of time constraint enables reflection, connection enables cooperation, while the combination of these two activities promotes effective individual and collaborative learning. One advantage of an asynchronous online discussion is the possibility of tracking all posts in discussions, which enables storing, following-up and analysing the process of knowledge creation (Lipponen, 2004). Bregar et al. (2010) explain that participants can examine contradictory statements, analyse various subjects, and mutually comment on various products, all of which promote learning with understanding. Since they have more time to process and understand this information, they can create a better and more considered contribution to the discussion (Brannon \& Essex, 2001; Downing \& Chim, 2004; Helleve, 2007; Robert \& Dennis, 2005). This is described as more in-depth reflection and reaction by Hrastinski (2008). Salmon (2004) stresses the significance of this effect on the motivation of participants who, when facing troubles, find out that their colleagues have similar problems. The disadvantages of such discussions are that they are time-consuming, participants do not feel part of the group, they participate too rarely, and do not get an immediate response to their contribution (Brannon \& Essex, 2001; Kear, 2004). Furthermore, demanding the involvement in the online discussion after the students have already completed their assignments might even become counter-productive, because the students do not find it beneficial anymore (K. J. Downing, Lam, Kwong, W.K. Downing, \& Chan, 2007). 
Murphy (2004) conducted a study in which she researched the collaboration of future teachers in an asynchronous online discussion. In order to measure the degree of collaboration among participants, she prepared a collaboration model, ranging from the lowest level of social presence to the creation of a common product (artefact). The model includes six phases in a continuum leading from interaction to collaboration between the discussants: (1) social presence, (2) articulating individual perspectives, (3) accommodating or reflecting the perspectives of others, (4) coconstructing shared perspectives and meanings, (5) building shared goals and purposes, and (6) producing shared artefacts. Using the model and indicators that designate each of the phases, she identified and analysed the contents and levels of posts in the online discussion. She found that the majority of posts appeared at the levels of social presence and opinion giving, and there were less posts at further levels expressing collaboration and not only interaction; for example, at the levels of accommodating or reflecting the perspectives of other participants, and constructing shared meanings. Only one post expressed a tendency to set common goals, while no post expressed the highest level, construction of a common artefact. Murphy (2004) explains that the key role in the systematic encouragement of the highest levels of collaboration between participants is that of the moderator and their planning. In an online discussion, it is important that the teacher sets clear goals, offers support to participants, and organizes the online experience in a way that encourages collaboration, the development of critical thinking, and common problem-solving. Costley and Lange (2016) also emphasize the meaning of clear goals and instruction, with a special focus on the tone of the discussion. They elaborate that the online discussion could miss the purpose of developing critical thinking and promoting student learning if the discussion revolves around the social presence of students and their peer bonding instead of the study assignments.

Quality learning takes place in a virtual or actual learning environment carefully designed by teachers who are energetic, committed and imaginative (Downing \& Chim, 2004). When reflecting on the role of the teacher as a moderator in an online discussion, we need to ask how much, when, in what way, and with what purpose the moderator should be involved in an online discussion of students. Anderson, Rourke, Garrison, and Archer (2001) point out three teacher's roles in creating an online educational environment. The first is the role of the creator of an interactive environment with precise goals and instructions for work, with the moderator presenting expectations regarding communication and participation in the online discussion and stressing that constructive criticism is expected, which means both agreement and disagreement with participants (Bryce, 2014; Anderson et al., 2001). The second role is that of the facilitator of the discussion, and the third is that of the guide of the discussion (Anderson et al., 2001). The moderator should not act from a position of superiority and power, but should promote supportive mutual relationships and thus also the process of reflection (Ma, 2008). All participants should be given equal opportunities for collaboration, since an authoritative tone used by one or more students might deter other participants from engaging in the discussion (Rovai, 2002).

Researchers agree that it is essential for any online discussion to be student-focused, and attribute different significance to the above-mentioned roles of the moderator. Some consider that the teacher should perform all three of the moderator's roles, while others believe that the roles of guiding and encouraging the online discussion can be partly taken over by one of the students. In a study carried out by Garrison and Cleveland-Innes (2005), it turned out that mere interaction between students in an online environment was insufficient for in-depth studies. They found that the teacher's teaching approach influences the change in a student's more in-depth study approach. The students who were included in an online study environment, in which the teacher led a focused critical discussion, significantly progressed in their in-depth study approach. Moreover, Wishart and Guy (2009) confirm that the moderator presents an important model for the students' critical behaviour development. With their probing questions of statements of confirmation, they set an example for student exchange in the online discussion. The moderator's scaffolding helped establishing a learning community in which the students shared their personal information and 
knowledge. Other studies exposed that participants in the discussion found the role of moderator in the online discussion to be less important than in traditional live discussions (Kelly, Ponton, \& Rovai, 2007), and they found information from colleagues to be of greater importance than the information from moderators (Kear, 2004). As a solution to this problem, Harris and Sandor (2007), together with Kear (2004), suggest the concept of an online discussion that includes the highest possible degree of peer-to-peer learning and collaboration. Instead of the teacher's traditional central role as a moderator who guides, encourages and leads the discussion, it is suggested that the moderator's role is taken by one of the participants, while the other participants are encouraged to be more actively involved in the discussion. The teacher thus adopts a more passive role and only monitors the dialogue. In principle, the teacher does not enter the discussion among students, except in cases when wrong notions are being spread, and in order to maintain an encouraging and productive group atmosphere (Kear, 2004).

\section{Summary}

Teaching practice plays an important part in the process of solidifying the connection between theory and practice. When gaining practical experience and being faced with diverse situations in an authentic environment, peer support, collaboration and interpersonal reflection are imperative, since they enable better preparation and implementation of teaching as well as a more in-depth self-reflection of these processes. If direct face-to-face communication between students is impossible, online communication provides a suitable replacement. Smith and Green (2013) confirm that online feedback and reflection provided support for beginning teacher education candidates who improved their lesson designing, implementing and evaluating skills, especially through learning university instructors' expectations. The online part of the blended course must certainly be well-planned and moderated to ensure a supportive social environment as the basis for quality cognitive work.

\section{Study Design}

This section describes the context in which the study was designed in order to explain the purpose of the research approaches that were used.

The research was carried out at the Faculty of Education, University of Ljubljana. This is the largest of the three institutions educating primary school teachers in Slovenia. The Primary Teacher Education Program mostly takes place in a face-to-face study environment. In order to bridge the gap between theory and practice, students experience teaching practice in primary schools in all five years of the program. They analyse and critically evaluate authentic problems from the fields of teaching and learning. In their first year, within the course Didactics with the Teaching Practice, students undergo a week of practical training in primary school where they experience real-life, authentic teaching environment and test themselves in the teacher's role for the first time. Although teaching practice mainly involves observing, the students also teach at least one lesson independently. For the first time they are deliberately included in all phases of teaching; that is, in the planning, implementation and evaluation of their own work.

During their teaching practice, when there was no direct contact between students, a part of the course was conducted by blending face-to-face and online performance (Figure 1). 


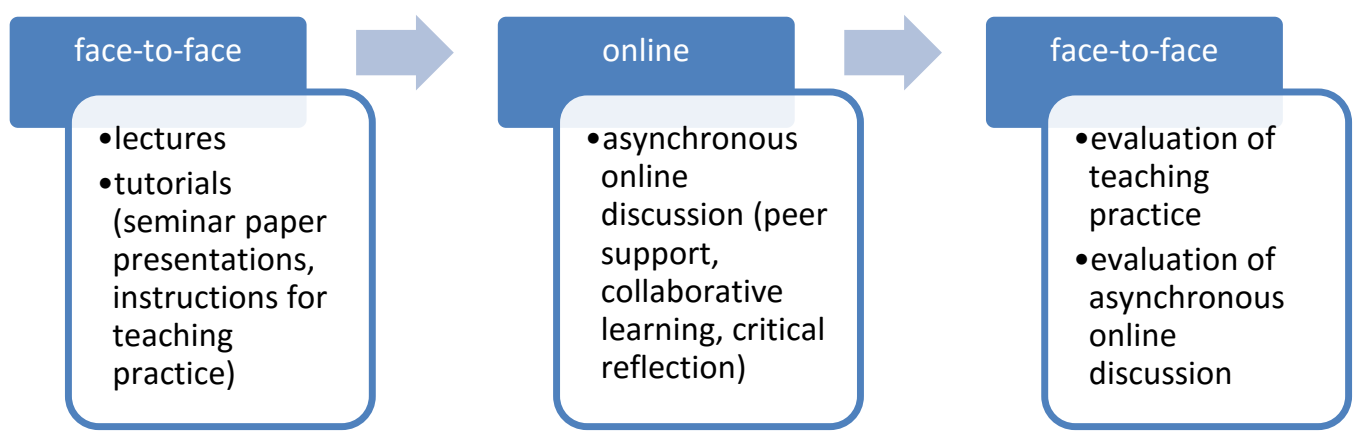

Figure 1: The design of the blended learning process

With the aim of providing multi-way communication to students during teaching practice at different schools throughout Slovenia, an online discussion was organised with the aim of enabling them to offer each other peer support, develop mutual relations, exchange ideas, perspectives and experiences, open issues and jointly search for answers to them, connect theory and practice in problem-solving and construct high-quality, useable knowledge for students. Figure 2 shows the supportive model that was designed with the intention of achieving these goals.

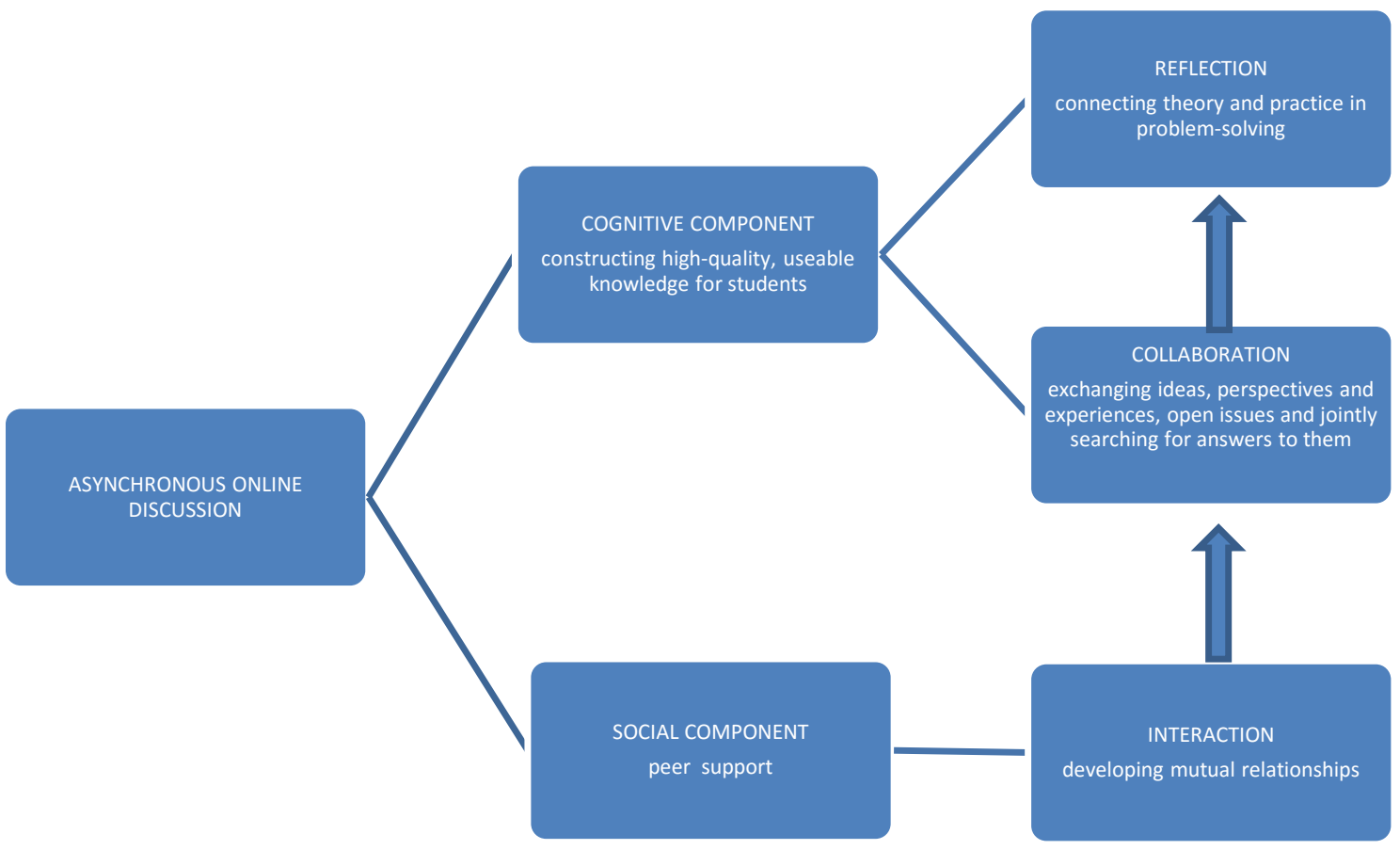

Figure 2: The supportive model with the structure of the asynchronous online discussion

The supportive model was a novelty that was introduced in the Didactics with the Teaching Practice course for the first time. Prior to that, an e-classroom had been used for several years, but communication was one-way only with the educator informing students about organization and content of the course. The supportive model with an asynchronous online discussion was designed in order to promote student collaboration and critical reflection through horizontal (student-to-student) rather than vertical (teacher-to-student) communication. Students' online posting and collaboration were meant to support students' face-to-face communication and learning process. 
In organizing an asynchronous online discussion for students, planning, preparation and structure are of extreme importance (Bassett, 2011). When planning the online discussion, we followed Dillenbourg's (2002) five-stage collaboration script (Table 1).

\section{Table 1: Five-stage collaboration script}

\begin{tabular}{|l|l|}
\hline Task definition & $\begin{array}{l}\text { Students post their lesson plans and add questions about the lesson plans } \\
\text { that still concern them. Each student's task is to comment the lesson } \\
\text { plans of all the other sub-group's members by: (a) answering the pro- } \\
\text { posed questions or dilemmas by the author of the lesson plan; (b) giving } \\
\text { praise for the parts that are well-planned; and (c) suggesting improve- } \\
\text { ments to the lesson plan. }\end{array}$ \\
\hline Group definition & Six sub-groups of five or six randomly selected members. \\
\hline Distribution & $\begin{array}{l}\text { Students are encouraged to comment on other students' previous com- } \\
\text { ments about lesson plans in order to develop a multi-way discussion. }\end{array}$ \\
\hline $\begin{array}{l}\text { Mode of interac- } \\
\text { tion }\end{array}$ & $\begin{array}{l}\text { Separate online discussion boards for each sub-group in the online class- } \\
\text { room. }\end{array}$ \\
\hline Timing & $\begin{array}{l}\text { Week 1: students introduce themselves to other members of their sub- } \\
\text { group and share some information about the school where their teaching } \\
\text { practice will take place. } \\
\text { Week 2 (teaching practice is in progress): students post their own lesson } \\
\text { plans and comment on each other's lesson plans. } \\
\text { Week 3: students report on how they implemented their lesson plans and } \\
\text { reflect on possible improvements. }\end{array}$ \\
\hline
\end{tabular}

In studying the usefulness of online discussion, we were guided by the following research questions:

- What are the intensity, level and content of students' posts in the online asynchronous discussion?

- How do students evaluate the usefulness of online discussion during their teaching practice?

- Were there any differences between the students who were included and those who were not included in the online discussion as regards their own evaluation of achieved objectives in teaching practice?

\section{Methodology}

\section{Participants and Group Formation}

A non-probability, purposive sample was used. The study included all of the 72 first-year students enrolled in the Primary Teacher Education study programme. All the first year students took the 15-week obligatory course entitled Didactics with Teaching Practice that is carried out in the first (winter) semester. Students had all come from different high schools in Slovenia and had not known each other from before. First, the sample was divided into two groups. The course was carried out in a usual face-to-face manner for the first group of students (39). For the second group of students (33), a supportive model with the online discussion was designed. This group of students was further randomly divided into six sub-groups of 5-6 members (named Sub-group A, Sub-group B, etc.). All the sub-groups participated in separate asynchronous online discussions. There were two moderators who prepared and monitored the collaborative tasks in the online discussions. A week before the teaching practice started, the students got specific instructions 
about the purpose of the online discussion as well as detailed instructions on how to establish a collaborative learning environment in the discussion sub-groups.

\section{Data Collection and Analysis}

The following were used to analyse the efficiency of the online discussion:

1) a descriptive method of analysing the data on the number of students' views and posts in each of the sub-groups participating in the online discussions;

2) a qualitative analysis of the level and content of the online discussion among its participants according to the collaborative model which was used in the process of coding the posts (Murphy, 2004);

3 ) in line with the quantitative paradigm of educational research a descriptive method of analysing data on the usefulness of online discussion (online survey for the students included in the asynchronous online discussion;

4) a causal-non-experimental method to establish differences in the assessment of achieved goals in teaching practice among the students included and those not included in the online discussion (comparison of data collected with an online survey for all students);

5) once the teaching practice was finished, a face-to-face meeting was organised where students evaluated the online discussion, which helped us to interpret the quantitatively collected data.

\section{The Issues of Validity, Reliability and Replicability}

To ensure reliability and consistency, we combined quantitative and qualitative research approaches. In the qualitative part, two different raters coded the data. Meanings of the coding categories (designed by Murphy, 2004) were discussed throughout the coding process and each example of the code was carefully chosen. To ensure internal validity, triangulation was used and, through that, reliability was also strengthened. There were multiple sources of data used in the study: the online discussion threads, questionnaires for students, and face-to-face whole-group evaluation of the experience with the online discussion. Triangulation was also achieved with multiple methodology approaches taken as well as the integration of different theoretical perspectives. External validity, related to the generalizability, was obtained by a thorough description of methodology, enabling other researchers to replicate the research and compare the findings.

\section{Results and Discussion}

This section presents and discusses the selected data analysis. The first part presents the intensity, level and content of the online discussion, which was analysed by following the discussion threads. The second part considers the results of the usefulness of the online discussion perceived by the included students. The third part deals with the comparison of the students' reported results about the achieved teaching practice goals between those who were included in the online discussion and those who were not.

\section{Analysis of the Intensity, Level, and Content of the Online Discussion}

In all sub-groups participating in the online discussion, the students introduced themselves and submitted their teaching materials. The level of participation in each sub-group is shown in Figures 3 and 4, which show the number of views and posts in the asynchronous online discussion by sub-groups members. Altogether, students viewed the discussion forums of their separate sub- 
groups for 2536 times and posted 140 comments. It is clearly evident that the number of views in all the sub-groups is much greater than the number of posts. This could be due to the fact that students were reading the posted discussions before making a decision on when to participate and what to post, which was also indicated in a study by Saade and Huang (2009).

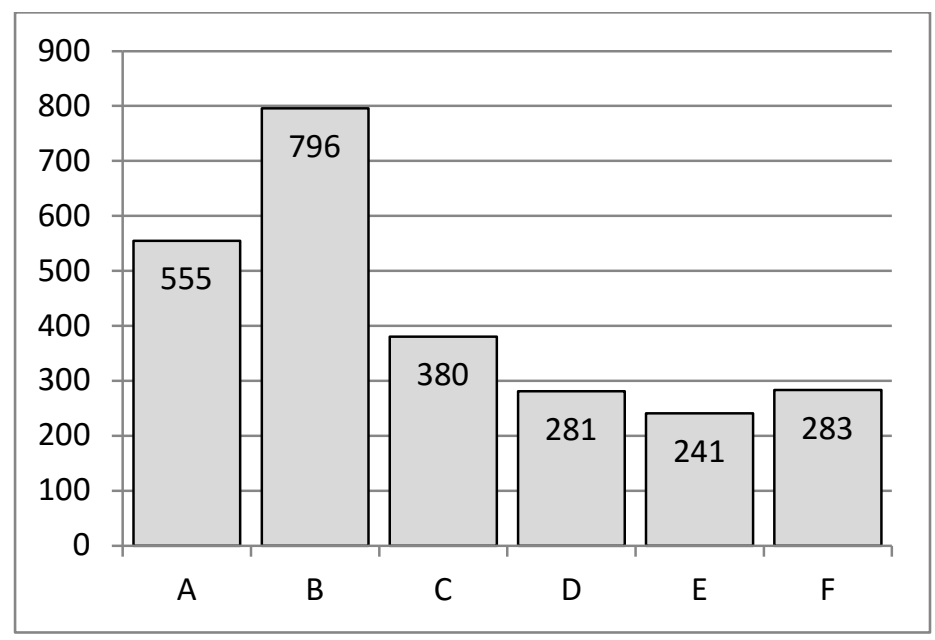

Figure 3: Number of views in sub-groups

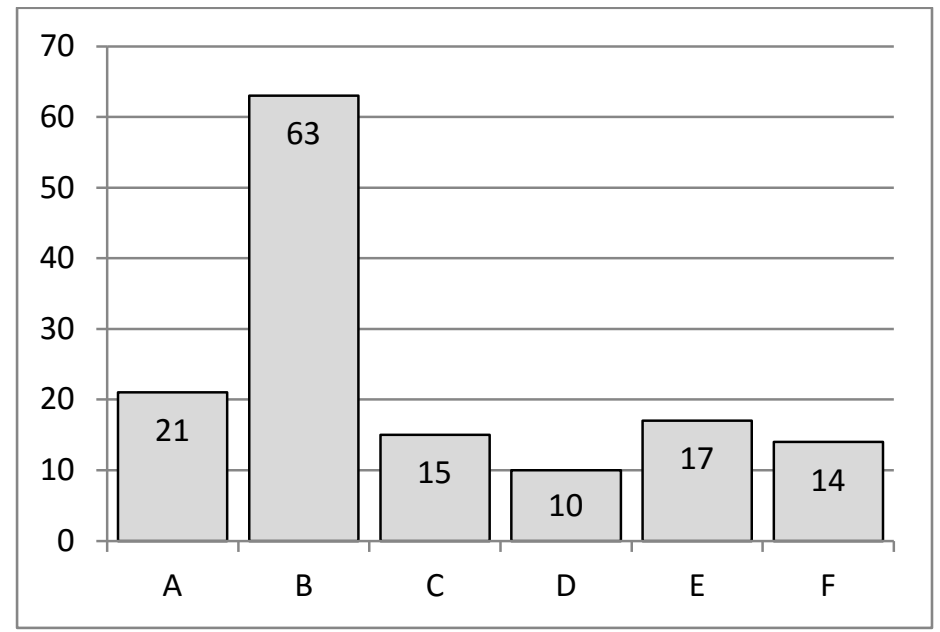

Figure 4: Number of posts in sub-groups

Figures 3 and 4 show that sub-group B had the highest numbers of views and posts. A closer look into the content of the sub-groups' online activity also confirms that the most active multi-way discussion took place in group $\mathrm{B}$, which will therefore be analysed in more detail further on. The sub-group members strictly observed the instructions and added some informal posts; for example, polite requests for comments, thanking in advance, icons for various emotional expressions (such as smileys), and so forth. This informal communication created a pleasantly relaxed work atmosphere and mutual trust, where everyone felt responsible to help each other prepare their lessons to the best of their ability.

In qualitative data analysis, a previously prepared model of participation in an online discussion was used (Murphy, 2004). This model was used to determine the nature of the assigned task and the extent to which it would enable collaborative learning. Table 2 presents the degrees, their indicators, and the cases in our study that correspond to these indicators. 
Table 2: Analysis of the online discussion in Group B according to the model of collaboration in online discussion (Murphy, 2004)

\begin{tabular}{|c|c|c|}
\hline Level & Specific Indicators & Examples \\
\hline \multirow[t]{6}{*}{ Social presence } & $\begin{array}{l}\text { Sharing personal infor- } \\
\text { mation }\end{array}$ & $\begin{array}{l}\text { 'My teaching practice will take place at the } \\
\text { primary school X. I will spend most of the } \\
\text { time in the fifth class, but I will also observe } \\
\text { other classes.' }\end{array}$ \\
\hline & $\begin{array}{l}\text { Recognising sub-group } \\
\text { presence }\end{array}$ & $\begin{array}{l}\text { 'The first day was great, so I'm looking for- } \\
\text { ward to the next, how was it at your schools?' }\end{array}$ \\
\hline & $\begin{array}{l}\text { Complimenting/ expressing } \\
\text { appreciation towards other } \\
\text { participants }\end{array}$ & 'Thanks for your help.' \\
\hline & $\begin{array}{l}\text { Expressing feelings and } \\
\text { emotions }\end{array}$ & $\begin{array}{l}\text { 'I'm looking forward to this opportunity, but } \\
\text { I'm also a little nervous, since I don't know } \\
\text { how everything will turn out.' }\end{array}$ \\
\hline & $\begin{array}{l}\text { Stating goals or purposes } \\
\text { related to participation }\end{array}$ & $\begin{array}{l}\text { 'I hope my opinion was helpful, please give } \\
\text { me your thoughts on the lesson plan I have } \\
\text { posted.' }\end{array}$ \\
\hline & $\begin{array}{l}\text { Expressing motivation } \\
\text { about project or participa- } \\
\text { tion }\end{array}$ & $\begin{array}{l}\text { 'My experience with the online discussion } \\
\text { was great, since our group was one of the few } \\
\text { that participated actively. My colleagues' } \\
\text { opinions, encouragement and advice were } \\
\text { useful to me.' }\end{array}$ \\
\hline \multirow[t]{2}{*}{$\begin{array}{l}\text { Articulating } \\
\text { individual per- } \\
\text { spectives }\end{array}$} & $\begin{array}{l}\text { Statement of personal opin- } \\
\text { ion or beliefs making no } \\
\text { reference to } \\
\text { perspectives of others }\end{array}$ & $\begin{array}{l}\text { 'I think you should show them both flutes, so } \\
\text { they have a chance to compare, look for dif- } \\
\text { ferences, and consequently develop cognitive } \\
\text { thinking.' }\end{array}$ \\
\hline & $\begin{array}{l}\text { Summarising or reporting } \\
\text { on content without refer- } \\
\text { ence to the } \\
\text { perspectives of others }\end{array}$ & $\begin{array}{l}\text { 'Your lesson plan is very interesting and I } \\
\text { think pupils will be thrilled about it. They are } \\
\text { still quite young, so it's important to teach } \\
\text { them through playing games, like you plan } \\
\text { to.' }\end{array}$ \\
\hline \multirow{5}{*}{$\begin{array}{l}\text { Accommodating } \\
\text { or reflecting the } \\
\text { perspectives of } \\
\text { others }\end{array}$} & $\begin{array}{l}\text { Directly disagreeing with/ } \\
\text { challenging statements } \\
\text { made by another participant }\end{array}$ & 'I don't think you need to read the story.' \\
\hline & $\begin{array}{l}\text { Indirectly disagreeing with/ } \\
\text { challenging statements } \\
\text { made by } \\
\text { another participant }\end{array}$ & $\begin{array}{l}\text { 'In my opinion, the lesson is very well } \\
\text { planned. I suggest you play the actual record- } \\
\text { ing of the song, so that pupils can figure out } \\
\text { which musical instruments are being used.' }\end{array}$ \\
\hline & $\begin{array}{l}\text { Introducing new perspec- } \\
\text { tives }\end{array}$ & $\begin{array}{l}\text { 'However, I think it's very important to in- } \\
\text { clude the pupils, who don't understand right } \\
\text { away, so that they don't feel excluded from } \\
\text { the lesson.' }\end{array}$ \\
\hline & Coordinating perspectives & $\begin{array}{l}\text { 'Thank you for your opinion, I didn't think of } \\
\text { the option I could participate in the activity } \\
\text { and increase pupils' motivation by doing } \\
\text { that.' }\end{array}$ \\
\hline & $\begin{array}{l}\text { Sharing information and } \\
\text { resources }\end{array}$ & 'This is the recording.' (link to the recording) \\
\hline
\end{tabular}




\begin{tabular}{|l|l|l|}
\hline \multicolumn{1}{|c|}{ Level } & \multicolumn{1}{c|}{ Specific Indicators } & \multicolumn{1}{c|}{ Examples } \\
\hline $\begin{array}{l}\text { Co-constructing } \\
\text { shared perspec- } \\
\text { tives and mean- } \\
\text { ings }\end{array}$ & $\begin{array}{l}\text { Asking for clarification / } \\
\text { elaboration }\end{array}$ & $\begin{array}{l}\text { 'I like the fact that you will play the flute for } \\
\text { them; if I understood correctly?' }\end{array}$ \\
\cline { 2 - 3 } & Posing rhetorical questions & $\begin{array}{l}\text { 'Will the pupils find the text interesting or } \\
\text { will they get bored?' }\end{array}$ \\
\cline { 2 - 3 } & Soliciting feedback & $\begin{array}{l}\text { 'I'm looking forward to your suggestions and } \\
\text { advice.' }\end{array}$ \\
\cline { 2 - 3 } & $\begin{array}{l}\text { Provoking thought and } \\
\text { discussion }\end{array}$ & $\begin{array}{l}\text { 'Do you think the text I've chosen will be too } \\
\text { difficult?' }\end{array}$ \\
\cline { 2 - 3 } & Responding to questions & $\begin{array}{l}\text { 'I think the text Peter Nos is appropriate and } \\
\text { they will not get bored.' }\end{array}$ \\
\cline { 2 - 3 } & Sharing advice & $\begin{array}{l}\text { 'I suggest you plan exactly what you will } \\
\text { dictate for them to write down, in order to be } \\
\text { systematic.' }\end{array}$ \\
\hline $\begin{array}{l}\text { Building shared } \\
\text { goals and pur- } \\
\text { poses }\end{array}$ & $\begin{array}{l}\text { Proposing a shared goal or } \\
\text { purpose }\end{array}$ & / \\
\cline { 2 - 3 } & $\begin{array}{l}\text { Working together towards a } \\
\text { shared goal }\end{array}$ & / \\
\hline $\begin{array}{l}\text { Producing shared } \\
\text { artefacts }\end{array}$ & $\begin{array}{l}\text { Document or other artefact } \\
\text { produced by sub-group } \\
\text { members working together }\end{array}$ & / \\
\hline
\end{tabular}

We found that members of sub-group B endeavoured to create comprehensive, in-depth and constructive posts. The sub-group members did not perceive the mutual comments as criticising, because they made it clear that these were only their contemplations, and that the author of the lesson plan would judge how much sense they made in their situation, for example:

"This is, of course, only my opinion; how you will proceed is completely up to you."

The students' posts appeared at the levels of social presence, articulating individual perspectives, accommodating or reflecting the perspectives of others, co-constructing shared perspectives and meanings. None of the posts could be classified in the last two levels of the model (building shared goals and purposes and producing shared artefacts). The reason for this lies in the concept of the students' task. Their mutual cooperation was focused on improving their respective lesson plans and not on planning and creating a common artefact. Murphy (2004) emphasizes that the systematic and concrete encouragement of higher levels of collaboration is necessary. We attempted to achieve this by structuring the task and providing thorough instructions for the online discussion. Thus students were asked to express their general concerns and dilemmas when planning a lesson, and to ask their colleagues concrete questions, which they eventually did, for example:

"Will my explanation be sufficiently interesting and clear? Will the pupils be sufficiently motivated or should I add anything?"

"I am a bit worried if we will be able to do everything in the time available. I also want to successfully deal with any restlessness in the classroom."

The commentators were given guidelines on what to focus on in their commenting. They expressed their own opinions, gave suggestions to the author and asked them questions because they wanted explanations or confirmation of having correctly understood the situation. They responded to the comments of other colleagues, as well as supported and supplemented them. In commenting, the students adhered to other instructions regarding the structure of comments. Their comments included praise of well-planned elements and suggestions for improvement. It is note- 
worthy that all their comments ended with an encouragement to the author, although this was not specified in the instructions. Examples of encouragement:

"Other than that, I feel you will teach the lesson excellently and that they will be motivated, as you will be including them all the time. Good luck!"

"I hope you perform well, too. Just enter the classroom bravely. Good luck!"

No such connectedness was detected in the other sub-groups of students included in the online discussion. Kear (2004) points out that different atmospheres of online discussion are established in various groups, even if the structure of the discussion, its content and moderators are the same. It became obvious that the atmosphere of the discussion depended mostly on the first contributions of individual students, while the moderator's task was to carefully monitor and maintain an encouraging and productive atmosphere in the discussion.

Social interactions among students are crucial to establishing relationships and trust among group members (Garrison \& Cleveland-Innes, 2005, Ma, 2013). In an early phase of their study, Downing et al. (2007) achieved that by asking the students to introduce one of their colleagues using the discussion board, which proved very effective in terms of creating a sense of belonging to a group. Garrison and Cleveland-Innes (2005) identify this process as the basis for further in-depth study. Ma (2013, p. 73) also confirmed that the affective roles played by the learners create supportive peer relationships which enable the development of critical reflection through honest and open confrontation based on argumentations.

\section{Analysis of the Usefulness of Asynchronous Online Discussion}

For a more comprehensive insight into the efficiency of online discussion, all the students who were included in the online discussion evaluated its usefulness in the areas of mutual communication and collaboration, as well as in learning. We refer to these two areas as the social and the cognitive components of online discussion.

\section{Analysis of the social component of online discussion}

Within the social component (Table 3), students assessed the degree to which they agreed with the statements regarding mutual relationships within their smaller online discussion group.

Table 3: Students' evaluations of the usefulness of online discussion - social component

\begin{tabular}{|l|c|c|}
\hline Social Component & $\bar{x}$ & SD \\
\hline All group members communicated in a respectful way. & 4,40 & 0,577 \\
\hline Communication between group members was sincere. & 3,60 & 1,080 \\
\hline Group members got to know each other well. & 3,27 & 0,874 \\
\hline Online discussion was time consuming. & 3,04 & 1,192 \\
\hline All group members participated in solving problems. & 2,50 & 0,906 \\
\hline
\end{tabular}

Note: Students assessed the usefulness of online discussion on a five-point scale from 1 - I totally disagree to 5 - I totally agree.

Students gave the highest average grade to the statement that all group members had adhered to the rules of respectful mutual communication. A somewhat lower average grade was attributed to the sincerity of group communication and to statement that the group members had become well acquainted with each other. Some of them were of the opinion that communication would have been more sincere and frequent had they been divided into sub-groups on a voluntary basis. However, other students saw an advantage in the randomised, previously determined division into sub- 
groups. Such a division enabled them to establish contacts and collaboration with fellow students, whom they were not yet acquainted with, thus expanding their social network.

The students' evaluations were most dispersed in connection with the statement that the online discussion was time-consuming for them. In their comments they mentioned three perspectives:

(1) too short time limits for handing in their lesson plans and commenting on the products of their colleagues; (2) feeling burdened in the period of their teaching practice; and (3) technical obstacles related to the slow internet connection and the lengthy procedure of entering the online classroom where the online discussion took place.

The lowest average assessment was given to the statement that all members participated in problem-solving. Considering the great dispersion of grades of all participating students we can confirm that average grades by sub-groups were quite different.

Table 4: Students' grading of the item "All group members participated in solving problems" in sub-groups

\begin{tabular}{|c|c|c|c|}
\hline Sub-group & $\bar{x}$ & $\min$ & $\mathbf{m a x}$ \\
\hline $\mathrm{A}$ & 2,66 & 2 & 3 \\
\hline $\mathrm{B}$ & 3,60 & 3 & 4 \\
\hline $\mathrm{C}$ & 2,60 & 2 & 3 \\
\hline $\mathrm{D}$ & 2,20 & 2 & 3 \\
\hline $\mathrm{E}$ & 1,66 & 1 & 2 \\
\hline F & 2,00 & 1 & 4 \\
\hline Together & 2,50 & 1 & 4 \\
\hline
\end{tabular}

Note: Students assessed the usefulness of online discussion on a five-point scale from 1 - I totally disagree to 5 - I totally agree.

Table 4 shows that students in sub-group B rated mutual collaboration in problem-solving with the highest average grade of 3.60. Members of other sub-groups rated this item with much lower average grades. Sub-group B was the most active group with the highest number of views and posts (Figures 3 and 4 ) and also created a very pleasant and supportive learning environment. These results confirm the findings of other research studies (Garrison \& Cleveland-Innes, 2005; Ma, 2013), which also found that creating a positive and honest atmosphere is the basis for the development of critical peer reflection and in-depth learning.

Members of other sub-groups that all graded their mutual collaboration in problem-solving with a much lower average grade, listed different reasons for their inactivity in the online discussion and in sending their comments about the lesson plans of their colleagues. Among the reasons, the students mentioned that the online discussion represented additional work to them, which they did not consider meaningful, that the sub-group members were not relaxed, and that not all students observed the deadlines and instructions. Chiong and Jovanovic (2012) also confirmed that low participation of other group members was one of the major reasons for students not to be active in the online discussion. Various other authors (Angeli, Valanides, \& Bonk, 2003; Downing et al., 2007; Kear, 2004) also highlight the problem of non-cooperation of all group members. For example, Kear (2004) found that in one online study programme, the active cooperation of all members of a particular group was recorded in as few as $45 \%$ of the groups. She stresses that this is particularly problematic in cases when cooperation in an online discussion is voluntary and if this element is not considered in the assessment of students' work. The author concludes her study with the observation that students participate in the discussion if they believe they will profit from such collaboration. For some students the only advantage is an acquired grade, while for others it is the usefulness of information. 
The study by Downing et al. (2007) also demonstrates that "students take a pragmatic approach to this process, disengaging when they feel they have all the information they need to complete the summative assessment task they are set" (p. 212). However, some students appreciate the discussion itself and the support obtained from other students in the discussion, which motivates them for learning (Chiong \& Jovanovic, 2012; Kear, 2004). This is well demonstrated in the comment of a student participating in our study who wrote:

"Well, as you have already commented my lesson, I will now comment yours."

In different studies (Chiong \& Jovanovic, 2012; Kear, 2004), students mentioned a lack of time for reading an excessive quantity of posts as an important reason for their inactivity in the online discussion. Garrison and Cleveland-Innes (2005) point out that the mere number of posts sent does not necessarily mean mental activity, and that students can be mentally active even if they are not involved in the discussion; that is, if they are only following it. Saade and Huang (2009) agree that the number of views indicates that students read the posted discussions and plan their participation rather than just placing a superficial comment or just going through the requirements of the course. One of the students in our study explained his online inactivity with the following words:

"I think I still lack knowledge and experience to advise my colleagues, since I didn't even know how to prepare a lesson myself."

\section{Analysis of the cognitive component of online discussion}

The purpose of an online discussion is to encourage quality study, because social interaction among students alone is not enough. Garrison and Cleveland-Innes (2005) point out as ideal the discussion in which a student shows their understanding of the problems through collaboration. Thus, students in our study also evaluated the cognitive component of the efficiency of online discussion (Table 5).

Table 5: Students' evaluations of the usefulness of online discussion - cognitive component

\begin{tabular}{|l|c|c|}
\hline Cognitive Component & $\bar{x}$ & SD \\
\hline Online discussion was helpful in the process of planning my lesson. & 3,32 & 0,723 \\
\hline Online discussion initiated in-depth reflection on problems. & 3,25 & 0,799 \\
\hline Online discussion was helpful in the process of evaluating my lesson. & 3,14 & 0,705 \\
\hline I got useful comments from other group members. & 2,62 & 1,169 \\
\hline
\end{tabular}

Note: Students assessed the usefulness of online discussion on a five-point scale from 1 - I totally disagree to 5 - I totally agree.

Students assessed that the online discussion was most helpful and supportive when preparing a lesson, and that it encouraged their in-depth reflection on problems.

During the face-to-face meeting after teaching practice, the students also expressed their views in person, namely, that by having an insight into the lesson plans of their colleagues, they had obtained new ideas for their own teaching, and that through their colleagues' comments, they had received confirmation of the adequacy of their thinking as well as answers to their questions and dilemmas. One of the students expressed the importance of online discussion in preparing a lesson with the following words:

"The opinions of my peers, as well as their encouragement and advice, helped me."

Students, through their individual reflection and the reflection of their colleagues, found it easier to become aware of the advantages and weaknesses of their planning and teaching. This enabled a higher quality of their teaching work, as pointed out by Kalin and Valenčič Zuljan (2006) who 
maintain that reflection is "the driving force of a teacher's professional development and actually makes it possible" (p. 152). They add that reflection helps the teacher to be aware of the present and future goals and the choice of effective strategies for their attainment.

Students attributed a rather lower grade to the statement that they had received useful comments from other members. Considering the great dispersion of grades, we attribute this to the fact that online communication and the exchange of opinions were very lively in some sub-groups, but almost non-existent in other. Table 6 shows average grades that students of different sub-groups attributed to the item "I got useful comments from other group members."

Table 6: Students' grading of the item "I got useful comments from other group members." in sub-groups

\begin{tabular}{|c|c|c|c|}
\hline Sub-group & $\bar{x}$ & $\min$ & $\max$ \\
\hline $\mathrm{A}$ & 2,00 & 2 & 2 \\
\hline $\mathrm{B}$ & 4,60 & 4 & 5 \\
\hline $\mathrm{C}$ & 2,40 & 2 & 3 \\
\hline $\mathrm{D}$ & 2,20 & 2 & 3 \\
\hline $\mathrm{E}$ & 1,66 & 1 & 2 \\
\hline F & 2,20 & 1 & 4 \\
\hline Together & 2,62 & 1 & 4 \\
\hline
\end{tabular}

Note: Students assessed the usefulness of online discussion on a five-point scale from 1 - I totally disagree to 5 - I totally agree.

The data analysis shows that members of sub-group B, who attributed the highest grade to the item "All group members participated in solving problems," also rated the usefulness of their colleagues' comments with a distinctively higher grade than members of other sub-groups. The connection between these two items is also clearly expressed in sub-group E that gave the lowest average grades to both items. We conclude that students perceive that participation of every subgroup member is important in the process of creating a supportive learning environment resulting in useful exchange of knowledge. Other recent studies have confirmed that there was a positive correlation between the quality of collaborative process in groups and the development of cognitive skills. Strong social interaction and collaboration contributed to the establishment of a learning community in which higher order thinking and co-creation of knowledge processes took place (Ma, 2009, 2013; Sorden \& Munene, 2013).

Nevertheless, caution should be taken, since an increase in social presence may lead to a decrease in critical thinking and vice-versa, warn Costley and Lange (2016). In their study, they found that once the discourse within a particular context has been set, students do not tend to change it.

Thus, too much social interaction may inhibit learning within a group. The moderator's task is to design instructions that will set the appropriate role and purpose of the online discussion. To conclude, the teacher should plan and monitor social contact between students, decide when the level of social interaction is optimal, and then encourage students to move on to cognitive tasks.

If we want the online interaction among students to grow from a social into a cognitive interaction, the presence and support of a moderator is mandatory, since online participation without mentoring or encouragement is most often only an exchange of one's own experiences and does not encourage in-depth thinking (Angeli et al., 2003; Garrison \& Cleveland-Innes, 2005). Ma (2013) emphasizes that the moderator should take appropriate and prompt intervention to help to resolve learners' conflicts arising of open argumentations, so that the group dynamic and mutual learning is not disturbed. 
In our supportive model of an asynchronous online discussion, there were two moderators who participated in the online discussion in three different roles (Anderson et. al., 2001); that is, as creators of an interactive environment, as facilitators of the discussion, and as guides of the discussion. The moderators' role in each sub-group discussion varied according to the intensity of conversation between students. In some sub-groups, the moderators only stimulated reflective exchange of opinions and in other sub-groups, complying with students' wishes, they also got involved in mutual reflection and answered students' questions. The moderators made sure that the students who sought moderators' feedback on their lesson plan got it. Students were thankful for the feedback and, in some cases, this was even an initiation of peer collaboration. Interestingly, one of the students expressed the opinion that sincere online communication in the sub-group of students had been hindered by the moderator's insight into their discussion.

In our study, we wanted to find out what the intensity, level and content of students' posts in the online asynchronous discussion were (research question 1). From the data analysis, we can see that, compared to other sub-groups, students in sub-group B had the highest numbers of views and posts in the online discussion. A thorough analysis of the level and content shows that members of sub-group B endeavoured to create comprehensive, in-depth and constructive posts. Their interaction created a pleasant atmosphere and mutual trust, where everyone felt responsible to help each other prepare their lessons.

Besides analyzing discussion post threads, we were also interested in students' perception of the usefulness of the online discussion. Students evaluated the social environment of the group as well as usefulness of collegial exchange of information on teaching and the reflection of this process. The second research question about the students' evaluation of the usefulness of online discussion during the teaching practice was answered by analyzing students' perceptions. They evaluated the social and cognitive components of the learning process. Our observations about the intensity, level and content of the online discussion were aligned with the students' perceptions about the quality and usefulness of the experience. The data analysis shows that members of subgroup B evaluated group members' participation in solving problems and also the usefulness of their colleagues' comments with a much higher grade than members of other sub-groups. We conclude that students value participation of every group member in the learning process.

\section{Influence of Online Discussion on the Attainment of Goals in Teaching Practice}

Considering the cognitive component in the efficiency of online discussion, we were interested if there were any statistically significant differences between the students who participated in the online discussion during their teaching practice and those who did not. The students evaluated their own progress in critical thinking and in the planning, implementation and evaluation of their teaching.

Among the topics evaluated by students in the above-mentioned fields, there were statistically significant differences in the evaluations of their own progress when reflecting on adapting their teaching, in the evaluations of their own criticism when analysing their implementation of a lesson, in their awareness of the connections between theory and practice, and in the critical evaluation of various opinions.

The students included in the online discussion reported a statistically significant higher evaluation of their own progress in adapting lessons and in their critical approach to analysing the implementation of a lesson compared to students who were not included in the online discussion. 
Table 7: Evaluation of students who were included and those who were not included in the online discussion regarding their own progress in critical thinking, and in the planning, implementation and evaluation of their teaching

\begin{tabular}{|c|c|c|c|c|c|c|c|}
\hline \multicolumn{8}{|c|}{ PROGRESS IN CRITICAL THINKING* } \\
\hline & $\begin{array}{l}\text { GROUP OF STU- } \\
\text { DENTS }\end{array}$ & $\begin{array}{c}1 \\
(\%)\end{array}$ & $\begin{array}{c}2 \\
(\%)\end{array}$ & $\begin{array}{c}3 \\
(\%)\end{array}$ & $\begin{array}{c}4 \\
(\%)\end{array}$ & $\begin{array}{c}5 \\
(\%)\end{array}$ & $\begin{array}{l}2 \hat{\mathrm{I}} \\
\mathrm{df}\end{array}$ \\
\hline \multirow[t]{2}{*}{$\begin{array}{l}\text { verbalising thoughts / } \\
\text { expressing opinion }\end{array}$} & $\begin{array}{l}\text { AOD } \\
\text { (students who par- } \\
\text { ticipated in the } \\
\text { asynchronous } \\
\text { online discussion) }\end{array}$ & 0 & 24 & 40 & 36 & 0 & \multirow{2}{*}{$\begin{array}{l}4,380 \\
3 \\
0,223\end{array}$} \\
\hline & $\begin{array}{l}\text { No AOD (students } \\
\text { who did not partic- } \\
\text { ipate in the asyn- } \\
\text { chronous online } \\
\text { discussion) }\end{array}$ & 0 & 14,5 & 58,2 & 23,6 & 3,6 & \\
\hline \multirow[t]{2}{*}{ argue statements } & AOD & 0 & 12 & 52 & 32 & 4 & \multirow{2}{*}{$\begin{array}{c}1,859 \\
4 \\
0,762\end{array}$} \\
\hline & No AOD & 3,6 & 12,7 & 52,7 & 29,1 & 1,8 & \\
\hline \multirow{2}{*}{$\begin{array}{l}\text { critical evaluation of } \\
\text { different opinions }\end{array}$} & AOD & 4 & 24 & 24 & 40 & 8 & \multirow{2}{*}{$\begin{array}{c}13,200 \\
4 \\
0,010\end{array}$} \\
\hline & No AOD & 0 & 9,3 & 53,7 & 37 & 0 & \\
\hline \multirow{2}{*}{$\begin{array}{l}\text { expressing opinion in a } \\
\text { respectful way }\end{array}$} & $\mathrm{AOD}$ & 8 & 8 & 20 & 52 & 12 & \multirow{4}{*}{$\begin{array}{c}3,189 \\
4 \\
0,527 \\
3,254 \\
4 \\
0,516 \\
\end{array}$} \\
\hline & No AOD & 1,9 & 7,4 & 35,2 & 64,3 & 9,3 & \\
\hline \multirow[t]{2}{*}{ accepting other opinions } & AOD & 8 & 8 & 40 & 32 & 12 & \\
\hline & No AOD & 3,7 & 9,3 & 24,1 & 42,6 & 20,4 & \\
\hline \multicolumn{8}{|c|}{ PROGRESS IN LESSON-PLANNING* } \\
\hline & $\begin{array}{l}\text { GROUP OF STU- } \\
\text { DENTS }\end{array}$ & $\begin{array}{c}1 \\
(\%)\end{array}$ & $\begin{array}{c}2 \\
(\%)\end{array}$ & $\begin{array}{c}3 \\
(\%)\end{array}$ & $\begin{array}{c}4 \\
(\%)\end{array}$ & $\begin{array}{c}5 \\
(\%)\end{array}$ & $\begin{array}{l}2 \hat{I} \\
\mathrm{df}\end{array}$ \\
\hline \multirow{3}{*}{ reflecting on lesson plan } & & & & & & & \multirow{3}{*}{$\begin{array}{c}2,951 \\
3 \\
0,399\end{array}$} \\
\hline & AOD & 0 & 8,3 & 8,3 & 54,2 & 29,2 & \\
\hline & No AOD & 0 & 1,8 & 18,2 & 54,5 & 25,5 & \\
\hline \multirow[t]{2}{*}{ reflecting on teaching } & AOD & 0 & 0 & 4,2 & 62,5 & 33,3 & \multirow{2}{*}{$\begin{array}{c}0,426 \\
2 \\
0,808\end{array}$} \\
\hline & No AOD & 0 & 0 & 7,3 & 56,4 & 36,4 & \\
\hline \multirow{2}{*}{$\begin{array}{l}\text { reflecting on the mean- } \\
\text { ing of instructional } \\
\text { goals }\end{array}$} & AOD & 4,2 & 0 & 25 & 41,7 & 29,2 & \multirow{2}{*}{$\begin{array}{c}6,035 \\
4 \\
0,197\end{array}$} \\
\hline & No AOD & 1,8 & 9,1 & 36,4 & 36,4 & 16,4 & \\
\hline \multirow{2}{*}{$\begin{array}{l}\text { reflecting on choosing } \\
\text { the appropriate teaching } \\
\text { method for a specific } \\
\text { instructional goal }\end{array}$} & AOD & 0 & 0 & 25 & 50 & 25 & \multirow{2}{*}{$\begin{array}{l}2,761 \\
3 \\
0,430\end{array}$} \\
\hline & No AOD & 0 & 3,6 & 32,7 & 49,1 & 14,5 & \\
\hline
\end{tabular}




\begin{tabular}{|c|c|c|c|c|c|c|c|}
\hline \multirow{2}{*}{$\begin{array}{l}\text { reflecting on choosing } \\
\text { the appropriate student } \\
\text { grouping pattern for a } \\
\text { specific instructional } \\
\text { goal }\end{array}$} & AOD & 0 & 0 & 20,8 & 45,8 & 33,3 & \multirow{2}{*}{$\begin{array}{l}5,111 \\
3 \\
0,164\end{array}$} \\
\hline & No AOD & 0 & 5,5 & 32,7 & 45,5 & 16,4 & \\
\hline \multirow{2}{*}{$\begin{array}{l}\text { reflecting on choosing } \\
\text { the appropriate activity } \\
\text { for a specific instruc- } \\
\text { tional goal }\end{array}$} & AOD & 0 & 0 & 12,5 & 45,8 & 41,7 & \multirow{2}{*}{$\begin{array}{c}6,188 \\
3 \\
0,103\end{array}$} \\
\hline & No AOD & 0 & 7,3 & 27,3 & 40 & 25,5 & \\
\hline \multirow{2}{*}{$\begin{array}{l}\text { reflecting on the appro- } \\
\text { priate articulation of the } \\
\text { lesson }\end{array}$} & AOD & 0 & 4,3 & 26,1 & 39,1 & 30,4 & \multirow{4}{*}{\begin{tabular}{|c|}
4,245 \\
3 \\
0,236 \\
$\mathbf{7 , 9 1 5 * *}$ \\
$\mathbf{3}$ \\
$\mathbf{0 , 0 4 8}$ \\
\end{tabular}} \\
\hline & No AOD & 0 & 16,4 & 29,1 & 40 & 14,5 & \\
\hline \multirow{2}{*}{$\begin{array}{l}\text { reflecting on adapting } \\
\text { the lesson to different } \\
\text { pupils }\end{array}$} & AOD & $\mathbf{0}$ & $\mathbf{0}$ & 37,5 & 29,2 & 33,3 & \\
\hline & No AOD & 1,8 & 10,9 & 30,9 & 40,0 & 16,4 & \\
\hline \multirow[t]{2}{*}{$\begin{array}{l}\text { becoming aware of the } \\
\text { connections between } \\
\text { theory and practice }\end{array}$} & AOD & $\mathbf{0}$ & $\mathbf{0 , 0}$ & 50,0 & 41,7 & 8,3 & \multirow{2}{*}{$\begin{array}{c}10,982 \\
3 \\
0,012\end{array}$} \\
\hline & No AOD & $\mathbf{0}$ & 16,4 & 25,5 & 38,2 & 20,0 & \\
\hline \multirow[t]{2}{*}{$\begin{array}{l}\text { becoming aware of } \\
\text { weaknesses }\end{array}$} & $\mathrm{AOD}$ & 0 & 4,2 & 20,8 & 41,7 & 33,3 & \multirow{2}{*}{$\begin{array}{c}2,838 \\
3 \\
0,417 \\
\end{array}$} \\
\hline & No AOD & 0 & 3,6 & 29,1 & 50,9 & 16,4 & \\
\hline \multirow[t]{2}{*}{$\begin{array}{l}\text { becoming aware of } \\
\text { strong points }\end{array}$} & AOD & 0 & 8,3 & 54,2 & 16,7 & 20,8 & \multirow{2}{*}{$\begin{array}{l}4,520 \\
3 \\
0,211\end{array}$} \\
\hline & No AOD & 0 & 12,7 & 40 & 36,4 & 10,9 & \\
\hline \multirow[t]{2}{*}{$\begin{array}{l}\text { planning for future } \\
\text { changes in teaching }\end{array}$} & AOD & 0 & 4,2 & 33,3 & 41,7 & 20,8 & \multirow{2}{*}{\begin{tabular}{|c|}
2,211 \\
3 \\
0,530 \\
\end{tabular}} \\
\hline & No AOD & 0 & 10,9 & 41,8 & 34,5 & 12,7 & \\
\hline \multicolumn{8}{|c|}{ TEACHING AND EVALUATION OF INSTRUCTION } \\
\hline & $\begin{array}{l}\text { GROUP OF STU- } \\
\text { DENTS }\end{array}$ & \multicolumn{2}{|c|}{$\begin{array}{l}\text { Yes. } \\
(\%)\end{array}$} & $\begin{array}{l}\text { Partly. } \\
(\%)\end{array}$ & \multicolumn{2}{|c|}{$\begin{array}{l}\text { No. } \\
(\%)\end{array}$} & $\begin{array}{l}2 \hat{\mathrm{I}} \\
\mathrm{df} \\
\mathrm{p}\end{array}$ \\
\hline \multirow{2}{*}{$\begin{array}{l}\text { I contributed most of the } \\
\text { ideas for the lesson } \\
\text { (content, goals, meth- } \\
\text { ods, patterns of student } \\
\text { grouping, etc.). }\end{array}$} & AOD & & & 20,8 & 70 & & \multirow[t]{2}{*}{$\begin{array}{l}0,823 \\
2 \\
0,663\end{array}$} \\
\hline & No AOD & & & 25,9 & 70 & & \\
\hline \multirow[t]{2}{*}{$\begin{array}{l}\text { I was prepared well for } \\
\text { the lesson. }\end{array}$} & $\mathrm{AOD}$ & & & 4,2 & 95 & & \multirow{2}{*}{$\begin{array}{c}2,422 \\
2 \\
0,298\end{array}$} \\
\hline & No AOD & & & 13 & 85 & & \\
\hline \multirow[t]{2}{*}{$\begin{array}{l}\text { I carried out the lesson } \\
\text { well. }\end{array}$} & $\mathrm{AOD}$ & & & 16,7 & 83 & & \multirow{2}{*}{$\begin{array}{c}0,183 \\
1 \\
0,668 \\
\end{array}$} \\
\hline & No AOD & & & 13 & 8 & & \\
\hline \multirow[t]{2}{*}{$\begin{array}{l}\text { I analysed the lesson } \\
\text { critically. }\end{array}$} & AOD & & & 8,3 & 91 & & \multirow{2}{*}{$\begin{array}{c}10,762 \\
2 \\
0,005\end{array}$} \\
\hline & No AOD & & & 38,9 & 57 & & \\
\hline
\end{tabular}




\begin{tabular}{|l|l|c|c|c|c|}
\hline $\begin{array}{l}\text { I gave suggestions on } \\
\text { how to improve my } \\
\text { future teaching. }\end{array}$ & AOD & 0 & 29,2 & 70,8 & $\begin{array}{c}3,965 \\
2 \\
\end{array}$ \\
\cline { 2 - 5 } & No AOD & 3,7 & 46,3 & 50 & 0,138 \\
\hline
\end{tabular}

Note*: Students assessed the usefulness of online discussion on a five-point scale from 1 - I totally disagree to 5 - I totally agree.

Note**: The value 2 Î was calculated for four categories (we merged categories 1 and 2).

In the phase of planning a lesson, the students were first focused on self-reflection of their lesson plans and then on interpersonal reflection between critical friends in the online discussion. In our opinion, the focused reflection and discussion of students who were included in the online discussion contributed to the higher quality of their thinking in the phase of preparing for teaching and in the phase of evaluating their teaching, thus resulting in a higher grade of their own progress. Smith and Greene (2013) have conducted a research in which they described the learning process of students who watched each other's lesson recordings online and analyzed them. Students reported that the experience of watching the videos, reflecting on them and getting feedback from peers helped them evaluate and improve their own planning, implementation and evaluation of instruction. They also stated that the blended learning design, with the combination of online and face-to-face, as well as teacher-student and student-student activities, is the most beneficial for their in-depth learning.

The students in our study who were not included in the online discussion reported a statistically significant higher evaluation of their own progress as regards their awareness of the connections between theory and practice, as well as the critical evaluation of different opinions, compared to students who were included in the online discussion. Our conclusion is that the results reflect a more critical approach on the part of students included in the online discussion in comparison to the students who were not. Namely, students not included in the online discussion had no insight into the thoughts and teaching plans of their colleagues, and thus had less opportunity to exchange and compare their considerations and those of their colleagues, and consequently less opportunity to gain a more complex insight into and understanding of their own actions.

In order to gain a more objective perspective of the usefulness of the asynchronous online discussion, we decided to compare perceptions of the achieved goals of the teaching practice between the students who were included in the online discussion and those who were not. We were interested in finding the differences between the two groups of students as regards their own evaluation of achieved objectives in teaching practice (research question 3). The students evaluated their own progress in critical thinking and in the planning, implementation and evaluation of their teaching. We found out that the focused reflection and discussion of students who were included in the online discussion contributed to the higher quality of their learning process, thus resulting in a higher grade of their own progress. The students who were not included in the online discussion had less opportunity to exchange and compare their ideas, and consequently less opportunity to gain a more complex insight into teaching.

\section{Limitations of the Study and Guidelines}

The research aimed at synthesizing quantitative findings based on the study of different aspects of the supportive model with an asynchronous online discussion to provide qualitative interpretation. The presented interpretation should, of course, be regarded as only one of a number of plausible interpretations. 
In generalizing the obtained study results their limits due to the number of the included students and the implementation of the online discussion should be kept in mind. Also, the students' posts in the online discussion and comments about this activity were only used to illustrate the quantitative data analysis. In future, formal coding and qualitative analysis of data should be used. When analysing the online discussion, students most often exposed a lack of time for cooperation, the technically awkward design of the online environment and the moderator's presence as barriers to their more frequent participation in the online discussion with colleagues.

To obtain more relevant data on the influence of an online discussion on peer support and learning, common searching for answers to questions, linking theory and practice in problem-solving and on encouraging the critical analysis of various ideas and the reflection of one's own work, a whole generation of students should be included in the online discussion and some substantive and technical solutions need to be improved. Online cooperation should become one of the students' obligations, in the frame of which they would solve educational problems prepared in advance. These should be designed according to CSCL principles, so that the solution can be reached only with mutual collaboration and discussion. The online discussion should last a longer period so that students have the time to get to know each other and then more time for active participation at the cognitive level to deepen their studies. This is also supported by Bassett 's (2011) findings, that students value flexible timelines that enable them to reflect on concepts and questions and then make more critical and creative contributions to the discussion. Grading of the student's frequency and level of contributions to the discussion, should also be considered. Wishart and Guy (2009) propose an appropriate model that could be followed in evaluating student's participation in the online discussion. The authors suggest the moderator should present evaluation criteria prior to opening the discussion, clearly stating the value of each post - e.g. no entry brings 0 points, descriptive entry brings 1 , interpretive comment is worth 2 points and generative response brings 3 points. Consequently, the students have guidelines for their contributions and the grading process based on their participation, becomes more transparent. Further research about the effectiveness of asynchronous online discussions regarding students' learning achievements should also be carried out. Technological support for identifying and rating participants' comments in the asynchronous online discussion could be provided by a tool for automatic analysis of text (e.g. ForumMiner by Azevedo, Reategui \& Behar, 2014). This kind of tool assists moderators and educators in evaluating student participation in an asynchronous online discussion.

The technical design of the online discussion should involve the further development of the web tool to enable faster and simpler access via computer and mobile accessories. The online discussion among students was also influenced by the moderator's involvement in the discussion. Although the moderator's involvement is essential for the in-depth study of students, the degree and the method of the moderator's participation in the discussion depend on the type of task and also on the participants' wishes. In future, moderators should individualize, as much as possible, their feedback to participants and pay attention to the impact of their inclusion on the atmosphere of trust established in the group. With more problem-focused tasks and a clear role of the moderator, higher levels of collaboration between students and a more in-depth reflection could be reached.

In this study we have focused on the first-year students with no prior teaching experiences. We have designed the asynchronous online discussion to enable peer learning and support in the first phase of the teaching process - planning a lesson. Future research could be expanded by including the other phases of teaching. Similar to Smith and Greene's (2013) study design, students could record their lessons, share the video in the online discussion forum and other students could evaluate their lesson through peer assessment. This kind of task would provide more learning input, enable stronger collaboration and more in-depth learning through critical reflection of each other's teaching. Although the asynchronous online discussion carried out in our study did not 
include a representative sample of students, it could be transferred to other study contexts. The peer-to-peer supportive model of study presents a framework on which other educators will be able to design, with various modifications, online discussions for their students and thus encourage their critical reflection in a collaborative environment.

\section{Conclusion}

We are aware of the importance of teaching practice within the scope of the study programme for the education of future teachers. Students also evaluate its significance highly and have great expectations in connection with it.

Through effective synthesis of theory and practice with the support of a valuable technological solution, this online experience provided a new blended model of university programs for teacher education. The online discussion was designed to encourage communication among students at a time when in-person collaboration was not possible. The emphasis of the online discussion was not only on exchanging information, but also on enabling and encouraging reflection of students' own teaching and that of their colleagues', as well as collaboration among students.

Within the framework of our research on the usefulness of online discussion we found that in the sub-groups where students failed to develop communication at the level of interpersonal relationships (social component), communication also failed to develop at the level of learning (cognitive component). The atmosphere of the discussion depended mostly on the first contributions of students, while the moderators' task was to monitor and maintain an encouraging and productive learning environment. We also found that online discussion helped students in the planning phase of a lesson, since ideas and comments by colleagues prompted them to investigate various aspects of preparation, to imagine beforehand the implementation of the lesson, and thus to invest additional effort in its preparation. Students perceive that participation of every group member is important in the process of creating a supportive learning environment resulting in useful exchange of knowledge. In assessing the achieved practical teaching goals, it became obvious that the online discussion positively influenced students' thoughts about modifying their teaching, as well as their critical approach to analysing the implementation of a lesson. The reflection, discussion and collaboration of students who were included in the online discussion contributed to the higher quality of their learning process, thus resulting in a higher perception of their own progress.

The implemented supportive model presents a significant contribution to the study process of future primary school teachers, since it introduces peer collaboration, reflection and group learning already in the first teaching practice experience, when they are initially faced with difficulties of being an inexperienced teacher. For many of them, the first teaching practice is a turning point at which they evaluate their own study program and career decisions, so peer support is invaluable to them.

When carrying out an asynchronous online discussion in future, more attention should be dedicated to the social aspect of communication as a basis for efficient cognitive collaboration, which, together with reflection and discussion, enables in-depth learning. In-depth study, based on reflection, collaboration and discussion about theoretical contents, along with the practical teaching experiences of students, stimulates the professional growth of future teachers and diminishes the obstacles at the beginning of their independent professional careers. 


\section{References}

Anderson, T., Rourke, L., Garrison, D. R., \& Archer, W. (2001). Assessing teaching presence in a computer conference context. Journal of Asynchronous Learning Networks, 5 (2), 1-17. Retrieved from http://cde.athabascau.ca/coi_site/documents/Anderson_Rourke_Garrison_Archer_Teaching_Presence. pdf

Angeli, C., Valanides, N., \& Bonk, C. J. (2003). Communication in a web-based conferencing system: The quality of computer-mediated interactions. British Journal of Educational Technology, 34 (1), 31-43.

Antoniou, P., Kyriakides, L., \& Creemers, B. (2011). Investigating the effectiveness of a dynamic integrated approach to teacher professional development. CEPS Journal, 1 (1), 13-42.

Azevedo, B. F. T., Reategui, E., \& Behar, P. A. (2014). Analysis of the relevance of posts in asynchronous discussions. Interdisciplinary Journal of E-Learning and Learning Objects, 10, 106-121.

Barron, B. (2003). When smart groups fail. The Journal of the Learning Sciences, 12 (3), 307-359.

Bassett, P. (2011). How do students view asynchronous online discussions as a learning experience? Interdisciplinary Journal of E-Learning and Learning Objects, 7 (1), 69-79.

Brannon, R. F., \& Essex, C. (2001). Synchronous and asynchronous communication tools in distance education: A survey of instructions. TechTrends, 45 (1), 36-42.

Bregar, L., Zagmajster, M., \& Radovan, M. (2010). Osnove e-izobraževanja [Basics of e-education]. Ljubljana: Andragoški center Slovenije.

Bryce, N. (2014). Teacher candidates' collaboration and identity in online discussions. Journal of University Teaching \& Learning Practice, 11 (1), 1-18. Retrieved from http://ro.uow.edu.au/cgi/viewcontent.cgi?article=1244\&context=jutlp

Chiong, R. \& Jovanovic, J. (2012). Collaborative learning in online study groups: An evolutionary game theory perspective. Journal of Information Technology Education, 11, 81-101. Retrieved from http://jite.informingscience.org/documents/Vol11/JITEv11p081-101Chiong1104.pdf

Costley, J., \& Lange, C. (2016). The relationship between social presence and critical thinking: Results from learner discourse in an asynchronous learning environment. Journal of Information Technology Education: Research, 15, 89-108. Retrieved from http://www.jite.org/documents/Vol15/JITEv15ResearchP089-108Costley1738.pdf

Dillenbourg, P. (2002). Over-scripting CSCL: The risks of blending collaborative learning with instructional design. In P. A. Kirschner (Ed.), Three worlds of CSCL. Can we support CSCL? (pp. 61-91). Heerlen: Open Universitiet Nederland.

Downing, K., \& Chim, T. M. (2004). Reflectors as online extraverts? Educational Studies, 30 (3), 265-276.

Downing, K. J., Lam, T. F., Kwong, T., Downing, W. K., \& Chan, S. W. (2007). Creating interaction in online learning: A case study. Research in Learning Technology, 15 (3), 201-215.

Garrison, D. R. (2003). Cognitive presence for effective asynchronous online learning: The role of reflective inquiry, self-direction and metacognition. Elements of quality online education: Practice and direction, 4, 47-58.

Garrison, D. R., \& Cleveland-Innes, M. (2005). Facilitating cognitive presence in online learning: Interaction is not enough, The American Journal of Distance Education, 19 (3), 133-148.

Harris, N., \& Sandor, M. (2007). Developing online discussion forums as student centred peer e-learning environments. ICT: Providing choices for learners and learning. Proceedings ASCILITE Singapore, 2007. 383-387. Retrieved from https://www.researchgate.net/publication/29466076_Developing_online_discussion_forums_as_studen t centred_peer_e-learning_environments

Helleve, I. (2007). In an ICT-based teacher-education context: Why was our group "the magic group"? European Journal of Teacher Education, 30 (3), 267-284. 
Hrastinski, S. (2008). Asynchronous and synchronous e-learning. Educause Quarterly, 31 (4), 51-55.

Jay, J. K., \& Johnson, K. L. (2002). Capturing complexity: A typology of reflective practice for teacher education. Teaching and Teacher Education, 18 (1), 73-85.

Kalin, J., \& Valenčič Zuljan, M. (2006). The role and types of reflection in teacher action research. In B. Kožuh, R. Kahn, A. Kozlowska, \& P. Krope (Eds.), Description and explanation in educational and social research (pp. 141-154). Los Angeles: UCLA.

Kear, K. (2004). Peer learning using asynchronous discussion systems in distance education. Open Learning: The Journal of Open, Distance and e-Learning, 19 (2), 151-164.

Kelly, H. F., Ponton, M. K., \& Rovai, A. P. (2007). A comparison of student evaluations of teaching between online and face-to-face courses. The Internet and Higher Education, 10 (2), 89-101.

Killion, J., \& Todnem, G. (1991). A process for personal theory building. Educational Leadership, 48 (6), 14-16.

Korthagen, F. (2004). In search of the essence of a good teacher: towards a more holistic approach in teacher education. Teaching and Teacher Education, 20 (1), 77-97.

Korthagen, F., \& Vasalos, A. (2005). Levels of reflection: core reflection as a means to enhance professional growth. Teachers and Teaching: Theory and Practice, 11 (1), 47-71.

Kreber, C. (2004). An analysis of two models of reflection and their implications for educational development. International Journal for Academic Development, 9 (1), 29-49.

Lipponen, L. (2004). From collaborative technology to collaborative use of technology: designing learning oriented infrastructures. Educational Media International, 41 (2), 111-116.

Ma, W. W. A. (2008). Computer supported collaborative learning and social creativity: A case study of fashion design. Journal of Information, Information Technology, and Organizations, 3, 17-40.

Ma, W. W. A. (2009). Computer supported collaborative learning and higher order thinking skills: A case study of textile studies. Interdisciplinary Journal of E-Learning and Learning Objects 5, 145-167. Retrieved from http://ijklo.org/Volume5/IJELLOv5p145-167MA657.pdf

Ma, W. W. A. (2013). Evaluating how the computer-supported collaborative learning community fosters critical reflective practices. Interdisciplinary Journal of E-Learning and Learning Objects, 9, 51-75. Retrieved from http://www.ijello.org/Volume9/IJELLOv9p051-075MaFT57.pdf

Mezirow, J. (1990). Fostering critical reflection in adulthood: a guide to transformative and emancipatory learning. San Francisco: Jossey-Bass.

Murphy, E. (2004). Recognising and promoting collaboration in an online asynchronous discussion. British Journal of Educational Technology, 35 (4), 421-431.

O'Hanlon, C. (1991). A risky business? The use of diaries in teachers' action research. In C. Ryan, \& B Somekh (Eds.), Processes of reflection and action (pp. 24-27). Norwich: Carn Publication.

Rebolj, V. (2008). E-izobraževanje: Skozi očala pedagogike in didaktike [E-education: The perspectives of pedagogy and didactics]. Radovljica: Didakta.

Robert, P. L., \& Dennis, R. A. (2005). Paradox of richness: A cognitive model of media choice. IEEE Transactions on Professional Communication, 48 (1), 10-21.

Romiszowski, A., \& Mason, R. (1996). Computer-mediated communication. In D. H. Jonassen (Ed.), Handbook of research on educational communications and technology (pp. 397-432). Mahwah, NJ: Lawrence Erlbaum.

Rovai, A. P. (2002). Sense of community, perceived cognitive learning, and persistence in asynchronous learning networks. The Internet and Higher Education, 5 (4), 319-332. 
Saade, G. R., \& Huang, Q. (2009). Meaningful learning in discussion forums: Towards discourse analysis. Issues in Informing Science and Information Technology, 6 (1), 87-99. Retrieved from http://iisit.org/Vol6/IISITv6p087-099Saade675.pdf

Salmon, G. (2004). E-moderating: The key to teaching and learning online. London and New York: Routledge Falmer.

Schollaert, R. (2006). Pomen sprememb v izobraževanju [The importance of changes in education]. In M. Turk Škraba (Ed.), Vpeljevanje sprememb v šole: konceptualni vidiki (pp. 9-18). Ljubljana: Zavod Republike Slovenije za šolstvo.

Schön, D. (1983). The reflective practitioner: How professionals think in action. New York: Basic Books, Inc.

Smith, J., \& Greene, H. C. (2013). Pre-service teachers use e-learning technologies to enhance their learning. Journal of Information Technology Education, 12 (1), 121-140.

Sorden, S. D., \& Munene, I. I. (2013). Constructs related to community college student satisfaction in blended learning. Journal of Information Technology Education: Research, 12, 251-270. Retrieved from http://www.jite.org/documents/Vol12/JITEv12ResearchP251-270Sorden1206.pdf

Stahl, G. (2005). Group cognition in computer-assisted collaborative learning. Journal of Computer Assisted Learning, 21 (2), 79-90.

Valenčič Zuljan, M., \& Vogrinc, J. (2007). Učiteljeva poklicna vloga in učiteljev profesionalni razvoj [The teacher's professional role and the teacher's professional development]. In M. Valenčič Zuljan (Ed.), Izzivi mentorstva (pp. 13-44). Ljubljana: Pedagoška fakulteta.

Valenčič Zuljan, M., \& Vogrinc, J. (2012). Pedagoška praksa i proces razvijanja kompetencija studenata budućih učitelja razredne nastave Pedagoškog fakulteta Sveučilišta u Ljubljani [Teaching practice and the process of the development of competences of student teachers studying at the Faculty of Education in Ljubljana]. In M. Valenčič Zuljan, G. Gojkov, A. Rončević, \& J. Vogrinc (Eds.), Pedagoška praksa i proces razvijanja kompetencija studenta budućih učitelja u Hrvatskoj, Srbiji i Sloveniji (pp. 109-136). Vršac: Vaspitačka škola Mihailo Palov.

Vogrinc, J., \& Valenčič Zuljan, M. (2009). Action research in schools - an important factor in teachers' professional development. Educational Studies, 35 (1), 53-63.

Ward, J. R., \& McCotter, S. S. (2004). Reflection as a visible outcome for preservice teachers. Teaching and Teacher Education, 20 (3), 243-257.

Wishart, C., \& Guy, R. (2009). Analyzing responses, moves, and roles in online discussions. Interdisciplinary Journal of E-Learning and Learning Objects, 5 (1), 129-144. Retrieved from http://ijklo.org/Volume5/IJELLOv5p129-144Wishart658.pdf

\section{Biographies}

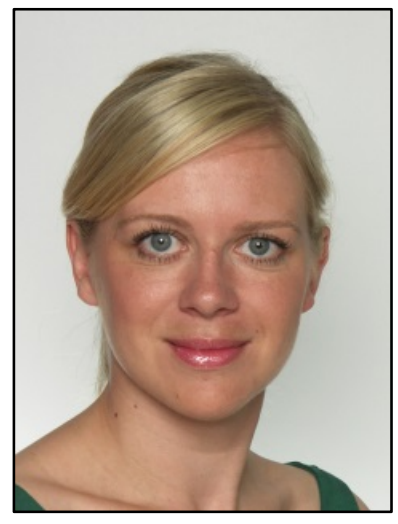

Romina Plešec Gasparič is a doctoral student and an assistant at the Faculty of Education, University of Ljubljana, Slovenia. Her research interests include practical teacher training for pre-service primary teacher students, within-class grouping practices in primary school, quality feedback in teacher education, and current topics in general didactics. 


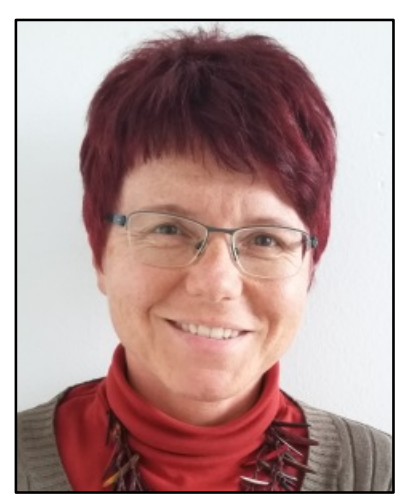

Mojca Pečaris a lecturer and a doctoral student at the Faculty of Education, University of Ljubljana, Slovenia. Her research interests include practical teacher training for pre-service primary teacher students, reflection of teaching practice in teacher education, partnership with teaching practice mentors, didactics of social science and differentiated instruction. 